\title{
THE ETERNITY SOLUTION TO THE PROBLEM OF HUMAN FREEDOM AND DIVINE FOREKNOWLEDGE
}

\author{
MICHAEL ROTA \\ University of St Thomas
}

\begin{abstract}
In this paper I defend the eternity solution to the problem of human freedom and divine foreknowledge. After motivating the problem, I sketch the basic contours of the eternity solution. I then consider several objections which contend that the eternity solution falsely implies that we have various powers (e.g. to change God's beliefs, or to affect the past) which, according to the objector, we do not in fact have.
\end{abstract}

\section{WHAT'S THE PROBLEM?}

Say that a human being $\mathrm{H}$ is free in the libertarian sense iff at least sometimes, (i) there are multiple possible alternatives for H's action, and (ii) it is up to $\mathrm{H}$ which alternative gets realized. ${ }^{1}$ There are some good reasons, I think, to believe that human beings are free in the libertarian sense. My main task in this paper, however, is not to defend the view that humans have libertarian freedom, but to discuss a problem for theists who believe that humans have libertarian freedom.

Regardless of your actual beliefs, suppose for a moment that you do believe that humans have libertarian freedom. And imagine that a friend of yours in the archaeology department asks you if you would be willing to help in an archaeological dig near Rome. You agree, and spend several weeks digging up artifacts in what was once a monastery in the seventh century A.D. You find various artifacts that have not seen the light of day for 1300 years. And then you find something exceptionally unusual. You

\footnotetext{
${ }^{1}$ I take this approach from Peter Unger, "Free Will and Scientiphicalism," Philosophy and Phenomenological Research 65 (2002): 1-25.
} 
yourself uncover a box containing a well-preserved Latin manuscript, buried all these long centuries. Being a well-trained Latinist, you begin to read the manuscript, and, to your astonishment, find that the manuscript contains a narrative of your entire life thus far. It names and describes your parents, identifies the day of your birth, and describes the subsequent course of your life - what career you have chosen, your professional accomplishments, and whom you have married.

You would no doubt initially think that this was an elaborate joke concocted by your archaeologist colleague. But suppose that you had convincing evidence that this was not so - suppose that you somehow had convincing evidence that the manuscript had really been there, buried in the dirt for 1300 years. Now, if you were indeed convinced that the manuscript was real, what would you think about your own freedom? How could you have been in control of your life, when the whole course of your life, including your most personal decisions, was laid out long before you were born?

In such a situation, your belief that you had been in control of your life would be shaken, I should think. Such a scenario would seem to provide good evidence that you did not have libertarian freedom.

The traditional Christian theist has a very similar problem. According to traditional Christian theism, God has perfect knowledge of events that are future with respect to us. On the traditional Christian view, before I was even born it was true that God knew the whole course of my life. Although there is no manuscript describing my life buried somewhere in the ground, there is something else which might seem even more problematic. A much more detailed, infallibly accurate account of my future life has been contained, as it were, in the mind of God, since long before I was born. How then, can any of my actions really be up to me?

\section{THE ETERNITY SOLUTION TO THE PROBLEM OF FREEDOM AND FOREKNOWLEDGE}

In this section I'll attempt to sketch a model according to which God can know all of our future actions, including our actions that are free in the libertarian sense. 
Suppose, with Boethius, Anselm, and Aquinas, that God is timelessly eternal. God is not located in the flow of time. He is outside time. Yet the events of all times are equally present to Him. The events of the temporal present are present to Him. But so are the events of last year, and the events of next year. They are all eternally present to Him.

If that's right, then we can tell a coherent story about how God could know what you will do tomorrow without taking away your freedom. Suppose that you will freely choose to answer the phone tomorrow at $9 \mathrm{am}$. Then God knows (eternally) that you will choose to answer the phone tomorrow at 9am simply because He sees you doing it. And God does not see you choosing to answer the phone before you actually do so. Rather, for God in eternity your action is a present event, not a future event. In Aquinas's words: “....all things which are in time are present to God from eternity... because His glance is cast over all things from eternity, as those things exist in their own presentness". ${ }^{2}$

So, you freely choose to answer the phone at 9am tomorrow. Because you choose this then, God knows that you choose this then. But just as my knowledge in the temporal present of what you are doing does not take away your freedom, so too God's knowledge in the eternal present of what you are doing does not take away your freedom. God has perfect knowledge of all events that are future with respect to us simply because He sees them occur.

The four key elements of the eternity solution, as I conceive it, are as follows:

(1) God is timelessly eternal.

Proposition (1) implies, among other things, that no part of God's life is before or after any other part of God's life. God's entire life is present all at once in eternity.

(2) For any time (including all times that are past with respect to us and all times that are future with respect to us, as well as the

${ }^{2}$ Summa Theologiae I.14.13c. Translations of Aquinas are my own. I use the text available at the Corpus Thomisticum website, http://www.corpusthomisticum.org/ iopera.html. 
temporally present time), and for any event or substance temporally located at such a time, that event or substance is present to God.

(3) For any time (including all times that are past with respect to us and all times that are future with respect to us, as well as the temporally present time), and for any event or substance temporally located at such a time, God has immediate knowledge of that event or substance.

(4) God knows events that occur in time because they occur, and not the other way around. (It is not the case that they occur because God knows that they occur).

Let's call this set of four propositions the Basic Divine Eternity Model, or, for short, the Basic Model. ${ }^{3}$

\section{OBJECTIONS RELATING TO POWERS}

I now turn to a group of related objections - each makes the contention that the Basic Model implies that we have powers that we do not, according to the objector, in fact have.

\subsection{Counterfactual power over God's eternal beliefs}

Suppose that an agent $\mathrm{S}$ performs an act $\mathrm{A}$ (say, makes a choice) at a time $\mathrm{T} 1$, but that at an earlier time T0, S had the power not to do A at T1. If God is eternal, then God eternally sees S doing A at T1, and so God eternally believes that $S$ does $A$ at T1. Now focus on that earlier time, T0. At T0, S had the power not to do A at T1. But if S had exercised that power, and not done A at T1, then either God would have had a false belief or God would never have eternally believed that $\mathrm{S}$ does $\mathrm{A}$ at $\mathrm{T} 1$ in the first place. It is impossible that God have a false belief. So, if S had not done $\mathrm{A}$ at T1, then God would not have eternally believed something that $\mathrm{He}$

${ }^{3}$ I call this the Basic Model because it can be developed in different ways, according to one's view about the nature of time. 
in fact does eternally believe. Thus, the eternity model (together with the claim that at T0 S has the power not to do A at T1) implies that, at T0,

(5) S has the power to do something ${ }^{4}$ such that if S did it, God would not eternally believe something that $\mathrm{He}$ does in fact eternally believe.

Note that proposition (5) does not imply that $S$ has the power to change or alter God's eternal beliefs, at least not in the normal sense of the word 'change'. Changing God's beliefs would involve making it such that God once had one belief, and then later did not have that belief (or making it such that God once did not have some belief, and then later did have that belief). But there's no question of that sort of thing here. If (first situation) S does do A at T1, then God eternally believes that $\mathrm{S}$ does $\mathrm{A}$ at T1. And if (second situation) S does not do A at T1, then God eternally believes that $\mathrm{S}$ does not do A at T1. There is no change in God's beliefs in the first situation. And there is no change in God's beliefs in the second situation. So in neither situation (actual or counterfactual) is there a change in God's beliefs. So in neither situation (actual or counterfactual) does $S$ do something that changes God's beliefs.

Now there is of course a difference between the two situations, and it is tempting to think that $S$ has the power to move us from being in the first situation to being in the second. We imagine that we are first in the first situation, in which $\mathrm{S}$ is going to do A at T1. But then, we imagine, $\mathrm{S}$ exercises his power not to do A at $\mathrm{T} 1$, and now we are in the second situation. When we imagine things in this way, it is natural to think that $\mathrm{S}$ can do something which would change God's beliefs, because by moving us from one situation to the other, $\mathrm{S}$ would be moving us from a situation in which God believes one thing, to a situation in which God believes something else.

But this involves a confusion - it is not in fact the case that $\mathrm{S}$ can do something which would move reality from being in the first situation (in which $S$ does $A$ at $T 1$ ) to being in the second situation (in which $S$ does not do $\mathrm{A}$ at $\mathrm{T} 1$ ). If $\mathrm{S}$ does not in fact do $\mathrm{A}$ at $\mathrm{T} 1$, then we were in the second situation all along. This is because what situation we are in depends

\footnotetext{
${ }^{4}$ I'm counting "refraining from doing A at T1" as something $\mathrm{S}$ could do.
} 
entirely on what $S$ does at $\mathrm{T} 1$. And since $S$ can do at most just one particular thing at $\mathrm{T} 1$, we must be in one particular situation all along.

So nothing about the eternity model requires that the power to change God's beliefs comes with the power to do otherwise. What does come with the power to do otherwise is the power to do something such that if one did it, God's eternal beliefs would be different than they are in the actual world. Call this counterfactual power over God's eternal beliefs.

\subsubsection{An objection to our having counterfactual power over God's eternal beliefs based on the fixed or settled character of eternity}

Some have objected that we could not really have such a power over God's eternal beliefs. ${ }^{5}$ Some remarks of Linda Zagzebski's suggest the following argument against my claim that we do have counterfactual power over God's eternal beliefs: 6

(For ease of expression I will develop this argument by talking about you and your power over God's eternal beliefs, but of course what I'll say would apply equally to everyone.)

The past is out of your reach, it is out of your control. No human being now has the power to do anything such that, if he did it, the past would have been different than it in fact is. And this is so because events in the past are fixed or settled. That is,

(6) Past events are out of your control because they are fixed or settled.

But if the reason that past events are out of your control is that they are settled, then any other sort of event that is settled will also be out of your control. So we have the general principle that

(7) If an event $\mathrm{E}$ is fixed or settled, then $\mathrm{E}$ is out of your control.

${ }^{5}$ See William Hasker, "The Absence of a Timeless God," in God and Time: Essays on the Divine Nature, ed. Gregory E. Ganssle and David M. Woodruff (Oxford: Oxford University Press, 2002), 198, and Linda Zagzebski, "Foreknowledge and Free Will," in The Stanford Encyclopedia of Philosophy (Fall 2008 Edition), ed. Edward N. Zalta, http://plato. stanford.edu/archives/fall2008/entries/free-will-foreknowledge/, section 2.2.

${ }^{6}$ Linda Zagzebski, The Dilemma of Freedom and Foreknowledge (New York and Oxford: Oxford University Press, 1991), 60-63, and "Foreknowledge and Free Will," section 2.2. 
And surely any event in eternity (any timeless event) is settled. "[W]hat can be more fixed than eternity?" Zagzebski asks. ${ }^{7}$ Suppose, for example, you perform some act A at a future time T1. Then, since God's believing anything is a timeless event (on the doctrine of divine eternity), we have,

(8) The timeless event of God's eternally believing that you do A at T1 is fixed or settled.

From (7) and (8), it follows that,

(9) The timeless event of God's eternally believing that you do A at T1 is out of your control.

But this implies that you do not have counterfactual power over God's eternal beliefs. For if you did have such a power, that is, if there was something you could do such that, if you did it, then God would not eternally believe that you do A at T1, then you would have the sort of control which (9) says you don't have. So by modus tollens,

(10) You do not have the power to do anything such that if you did it, God would not eternally believe something that He does in fact eternally believe.

Although I grant that this argument is initially appealing, I think it has a serious flaw. We need to ask what "fixed" means. If "fixed" merely meant "not in your control" than (6) would be circular (the past is out of your control because it is out of your control). What's left is to interpret "fixed" as meaning "settled" or "actually a certain way", as I have done. But then (7) is false, as we can see by focusing on the temporal present. ${ }^{8}$ Suppose you do A at T1. When T1 is the present time, you are doing A. But events in the temporal present are settled just as much as events in the past. At T1, it is a settled matter that you are doing A at T1. (7) would have us conclude that your doing A is therefore out of your control. But

${ }^{7}$ Linda Zagzebski, The Dilemma of Freedom and Foreknowledge, 60.

${ }^{8}$ Katherin Rogers uses this strategy in "The necessity of the present and Anselm's eternalist response to the problem of theological fatalism," Religious Studies 43:1 (March 2007), 25-47. 
given that you have libertarian freedom with respect to A, this is false. So (7) is false.

Next: if (7) is false, the mere fixedness of an event is not that which explains why that event is out of your control. So the premise that

(6) Past events are out of your control because they are fixed or settled,

is false as well.

In my view, the brief argument just given successfully defeats the objection we're now considering. But we still might wonder, what does explain the common intuition that past events are out of our control, if not the fixedness of the past? I suggest that the real reason we tend to think that past events are out of our control is that we tend not to think that any action we can perform has the sort of causal or explanatory connection to past events that is required for control over those past events.

To explain what I have in mind, I'll begin with a paradigm case of an event that is in my control. Suppose that one minute from now I will freely walk across the room. Then the future event of my walking across the room is something that is in my control. Why do I have control over this event? Simple: I have control over this event because I can cause it to occur. I can will to stand up and will to move my legs in the right way, and thereby cause the event of my walking to take place. More generally, if it is (really) in my power to efficiently cause an event to occur, then that event is not out of my control. I have control over those future events that I can be causally connected to via a chain of efficient causation. ${ }^{9}$

Of course, the future event of my walking across the room would not be in my control if I were not in control of my own act of willing to walk across the room. The source of my control over future events involving my body and future events caused by my body is to be found in my control over my own acts of will. While my control over walking across the room is indirect (it comes via my control over my own will), at some point there must be some basic act I perform over which I have direct control. A choice - or, as we might say, an executive intention - is a plausible candidate for such an act.

${ }^{9}$ More exactly: I have control over those future events such that (a) I can bring them about, and (b) it is up to me whether I bring them about. 
In addition to future events that I cause, then, there are present events that I have control over. I have control over my own acts of free choice, which I agent-cause. Suppose that at a time T, I freely make a choice - call this act A. So I do A freely at T. A is a basic action - it is not the case that I do A by doing something else which in turn brings about A. Rather, A occurs, it is caused by me (the substance), and the fact that A occurs is up to me. And it is up to me even as I do it, that is, it is in my control even at $\mathrm{T}$. This is true despite the fact that at $\mathrm{T}$, it is a fixed fact that A occurs. I do not see that a libertarian can plausibly say anything else about acts of choice.

Let's use the phrase "direct control" to refer to the sort of control I have over my acts of choice. We can then say that I have indirect control over certain events (for example, my walking across the room) that are causally consequent to those events over which I have direct control.

Next, I also have indirect control over certain events, or states of affairs, ${ }^{10}$ that are explanatorily consequent to events I have direct control over. For example, suppose I do A at T, and I have control over my doing $\mathrm{A}$ at $\mathrm{T}$. Let $\mathrm{P}$ be the proposition that I do A at T. Now consider the state of affairs consisting in P's being true. The fact that I do A at T makes the proposition $\mathrm{P}$ true. That is, my doing $\mathrm{A}$ at $\mathrm{T}$ is the truthmaker for $\mathrm{P}$. $\mathrm{P}$ is true because I do $\mathrm{A}$ at $\mathrm{T}$, and not the other way around. ${ }^{11}$

A word of explanation: I've stopped talking just in terms of 'events' and started talking in terms of 'states of affairs'. I've done this because I hesitate to call P's being true an event. (A proposition's being true isn't something that happens, it seems to me.) We need some name for it, though, so I'll use 'state of affairs' in such a way that P's being true counts as a state of affairs. I'll also count anything we can call an event as a state of affairs. So I'll use 'states of affairs' to name a broader category which includes events. ${ }^{12}$

${ }^{10} \mathrm{I}$ insert "or state of affairs" in case things like its being the case that a given proposition is true do not count as events. I will stipulate that 'state of affairs' includes bona fide events as well as a proposition's being true, if a proposition's being true is not a bona fide event.

${ }^{11}$ I'm helped here, and throughout this section, by Trenton Merricks, "Truth and Freedom," Philosophical Review 118:1 (2009): 29-57.

${ }^{12}$ I take the general idea for this strategy from Linda Zagzebski, The Dilemma of Freedom and Foreknowledge, 13. 
Now, when we say that the proposition $\mathrm{P}$ is true because I do A at $\mathrm{T}$, the "because" here does not signify the relation of efficient causation. (I don't literally cause $\mathrm{P}$ to be true, in the way that I cause a billiard ball to move.) So we can't properly say that P's being true is causally consequent to my doing $\mathrm{A}$ at $\mathrm{T} .{ }^{13}$ But we can say that P's being true is explained by the fact that I do A at T. As I'll put it, the state of affairs consisting in P's being true is explanatorily consequent to my doing $\mathrm{A}$ at $\mathrm{T}$. In general, I say that a state of affairs $\mathrm{S} 2$ is explanatorily consequent to a state of affairs S1 iff the obtaining of S1 explains (at least in part) why S2 obtains.

If we grant that we have libertarian freedom, then it seems clear that, in addition to certain future events and my present acts of choice, I have control over certain states of affairs that are explanatorily consequent to events over which I have control. For example, I have control over P's being true, simply because I have control over the fact that I do A at T. ${ }^{14}$

Let's return now to

(6) Past events are out of your control because they are fixed or settled.

I gave an argument above that (6) is false. I'm now trying to do something different than just argue that (6) is false: I'm trying to offer an explanation of why the proposition "past events are out of our control" is so attractive and intuitively plausible. And now that we have the language of causal and explanatory consequence on the table, I can state my diagnosis fairly quickly: people typically believe that past events are beyond our control because they typically believe that we do not have direct control over any events that will cause or explain a past event.

An indication that I'm right here is this: if we all suddenly believed in backwards causation (that is, if we all believed that a temporal event at a later time could causally bring about a temporal event at an earlier time), then we would be open to the possibility that a past event could be in someone's control.

${ }^{13}$ Not given that, in contemporary idiom, we usually mean 'efficient cause' when we speak of causal consequence.

${ }^{14}$ See Trenton Merrick's second corollary in "Truth and Freedom," 42. 


\subsubsection{A positive argument that we have counterfactual power over God's eternal beliefs}

I now give a positive argument for the claim that we have counterfactual power over God's eternal beliefs. The fourth proposition of the model I am defending is:

(4) God knows events that occur in time because they occur, and not the other way around.

Suppose, again, that I do A at T. It follows from (4) that God eternally believes that $\mathrm{I}$ do $\mathrm{A}$ at $\mathrm{T}$ because I do $\mathrm{A}$ at $\mathrm{T}$. But then if my doing $\mathrm{A}$ at $\mathrm{T}$ is in my control, the state of affairs of God's eternally believing that I do A at $\mathrm{T}$ should also be in my control. For if a second state of affairs depends on a first, and I have control over the first, then I have control over the second. And the state of affairs consisting in God's eternally believing that I do A at $\mathrm{T}$ does depend on the state of affairs consisting of my doing A at T. Since I have control over my doing A at T, it follows that I have control over God's eternally believing I do A at T. And, mutatis mutandis, the same goes for you, and everybody else with libertarian free will.

I myself find the language of explanatory consequence helpful for discussing our counterfactual power over God's eternal beliefs. I asserted above that we have control over states of affairs involving the truth of propositions about events over which we have control. So, for example, if my doing $\mathrm{A}$ at $\mathrm{T}$ is something I have control over, then P's being true is also something I have control over. ${ }^{15}$ And I've used the language of explanatory consequence to describe the relation between my doing $\mathrm{A}$ at T and P's being true: P's being true is explanatorily, though not causally, consequent to my doing $\mathrm{A}$ at $\mathrm{T}$.

Now, on the model I'm defending, God's eternal beliefs about our free actions are also explanatorily consequent to our free actions. For example, the event (E3) of God's eternally believing that I do A at T is explained by the event (E2) of God's eternally seeing that I do A at T, which is in turn explained by the event (E1) of my doing A at T. So God's

\footnotetext{
${ }^{15} \mathrm{P}$ is the proposition that $\mathrm{I}$ do $\mathrm{A}$ at $\mathrm{T}$.
} 
eternally believing that I do A at $\mathrm{T}$ is explanatorily consequent to my doing $\mathrm{A}$ at $\mathrm{T} .{ }^{16}$

How is it that we have counterfactual power over God's eternal beliefs? In general, we have control over events and states of affairs which are causally and/or explanatorily consequent to events over which we have direct control. In this case, we have control over God's eternal beliefs about our free actions because such beliefs are explanatorily consequent to our free actions.

\subsubsection{Do we ever exercise this power? Can we?}

It's worth asking whether we ever exercise our counterfactual power over God's eternal beliefs. Suppose I have the power to do A at some future time T1, but I will in fact refrain from doing A at T1. I now have the power to do A at T1 (let now be T0, earlier than T1). ${ }^{17}$ Because I in fact refrain from doing $\mathrm{A}$ at $\mathrm{T} 1$, God eternally believes that I do not do A at T1. It follows that

(11) I now (at T0) have the power to do something (A at T1) such that if I were to do it, God would not have eternally believed something that He does eternally believe in the actual world.

Do I ever exercise such a power? In one sense, no; I never actually do anything such that my doing it brings it about that God does not eternally believe something which He does eternally believe in the actual world. But in another sense, yes; for the power referred to in (11) is really just my power of free action, and I exercise that frequently. What's going on here, exactly?

The situation is just the same with the power to do otherwise. For example, still supposing that I in fact refrain from doing A at T1, the libertarian can say:

(11a) I now (at T0) have the power to do something (A at T1) other than what I will do in the actual world.

${ }^{16}$ Given divine simplicity, E3 and E2 are not really distinct.

${ }^{17}$ I myself think that even at T1 I have the power to do A at T1, but here I will just work with the claim that at T0 I have the power to do A at T1. 
Do I ever exercise this power, the power to do otherwise? In one sense, no; I never actually do anything other than what I do in the actual world. But in another sense, yes; my power to do otherwise is just my power of free action, and I exercise that frequently.

It can seem strange that I would have a power that I never exercise. Upon reflection, however, we can understand the reason why we never exercise such a power as the power to do otherwise, under that description, or the power to make God's beliefs other than what they in fact are, under that description. The reason is that the very description of the power includes a stipulation that entails that the something (which we are said to have the power to do) does not occur in the actual world. So of course we never actually exercise such a power by doing such a something.

Still, it would be wrong to think that this fact poses a problem for the claim that we have such a power. Ontologically, the referent of the power mentioned in claims like (11) and (11a) is just my power of free action. ${ }^{18}$ So the power referred to in (11) and (11a) does get exercised, it simply does not get exercised to perform an action falling under the description given in (11) or (11a). But that's just to say that it does not get exercised to perform an action that does not occur in the actual world. That can't be a problem.

There is a sense, then, in which we never actually exercise our counterfactual power over God's eternal beliefs. We never exercise our power of free action by doing something that falls under the description "something that accounts for its being the case that God's eternal beliefs are different than what they are in the actual world". We never exercise the power in that sense or way. Next question: could we exercise it in that sense or way? Yes, so long as we interpret 'the actual world' in statements like (11) as a rigid designator.

To see this, return to the example used in connection with (11). Let a rigidly designate the actual world. In $\alpha$, I refrain from doing $\mathrm{A}$ at $\mathrm{T} 1$, and God eternally believes that I do not do A at T1. Let W be a possible world in which I do A at T1. In W, God does not eternally believe something (viz., that I don't do A in T1) that He does eternally believe in $\alpha$.

${ }^{18}$ Maybe my power of free action is best thought of as a set consisting of my power of free will plus various powers of bodily movement. I'll leave this complication to the side and just talk about my power of free action. 
So in W, I do something that accounts for its being the case that God's eternal beliefs are different than what they are in $\alpha$. Since $\mathrm{W}$ is a possible world, we can say (in $\alpha$ ) that I could do something that would account for its being the case that God's eternal beliefs are different than what they are in $\alpha$. Thus, I could exercise counterfactual power over God's eternal beliefs even in the sense in which I never actually do exercise it.

\subsection{Counterfactual power over certain past truths}

On the model I'm defending, we also have power over certain past truths. Suppose that Smith does A at $\mathrm{T}$ (some time in 2008). And suppose that on the day of Smith's birth, in 1958, someone uttered the following sentence: "God eternally believes that Smith does A at T". Given divine eternity, that sentence expressed a truth, way back then in 1958. So, we have:

(12) In 1958, the sentence "God eternally believes that Smith does A at T" expressed a truth.

Let the letter S denote that sentence uttered back in 1958, "God eternally believes that Smith does A at T." Notice that if Smith had refrained from doing A at T, God wouldn't have eternally believed that he does A at T, so $\mathrm{S}$ would not have expressed a truth, not in 1958 or at any time. And let us suppose that Smith has the power (in 2008) to refrain from doing $\mathrm{A}$ at $\mathrm{T}$. Then Smith has the power in 2008 to do something (refrain) such that, if he were to do it, the sentence $S$ would not have expressed a truth back in 1958. (Even though $S$ did, in fact, express a truth back then, and 1958 is over and done with.) Call this counterfactual power over the past truth of S. It appears that the view I'm defending leaves us with the conclusion that

(13) Smith has the power (in 2008) to do something such that, if he were to do it, then the state of affairs of S's expressing a truth (a state of affairs that obtained in 1958 in the actual world), would not have obtained in 1958.

I concede that the Basic Model has this implication. But I deny that this is a difficulty for the view. Given divine eternity, Smith does indeed 
have the power described in (13), as I'll now argue. Let's begin with a question: what explains the fact that $S$ expressed a truth in 1958? Well, S expressed a truth back in 1958 because God eternally does believe that Smith does A at T. And why does God eternally believes that Smith does $\mathrm{A}$ at T? Because Smith actually does do A at T. So S's expressing a truth in 1958 is explanatorily consequent to God's eternally believing that Smith does $\mathrm{A}$ at $\mathrm{T}$, which is in turn explanatorily consequent to Smith's doing A at T. But a state of affairs which is causally and/or explanatorily consequent to an event that is up to Smith is itself up to Smith. Since it is up to Smith that he does $\mathrm{A}$ at $\mathrm{T}$, it is up to Smith that $\mathrm{S}$ expresses a truth back in 1958.

Or we could use the language of control: if it is in Smith's control that he does $\mathrm{A}$ at $\mathrm{T}$, then it is in Smith's control that $\mathrm{S}$ expresses a truth in 1958. Or the language of "being in one's reach": if the action of doing A at $T$ is within Smith's reach, then the state of affairs of S's having expressed a truth in 1958 is within Smith's reach, ${ }^{19}$ because the second depends entirely on the first, and the first is within Smith's reach..$^{20}$

If you still find yourself skeptical of the conclusion that Smith has counterfactual power over the past truth of propositions about his free actions, consider the following three points. First, the power in question is not a power to change the past. Smith's having the power described in (13) does imply that something about the past is now up to him (the 'something' is the state of affairs, obtaining in 1958, of S's expressing a truth). But it does not imply that he can change the past, for a reason parallel to that given above in the discussion of counterfactual power over God's eternal beliefs. Changing the past would involve bringing it about that the past is now one way, after earlier having been a different way. But (13) does not imply that there is any possible world in which Smith brings that about.

Second, this is a power no one ever actually exercises. (Although it could be exercised.)

Third, so long as it is granted that future contingent propositions have a truth value, the same puzzle is generated simply by the problem of logical

${ }^{19}$ Within his reach to account for, not within his reach to change. See below, next paragraph.

${ }^{20}$ I'm helped here by Trenton Merricks, "Truth and Freedom," 42. 
fatalism, quite apart from theological considerations. So if we think there is an answer to logical fatalism, we should not be troubled by (13).

\subsection{Counterfactual power over genuine past events}

And now for a more difficult objection. . .I have just argued that, given the Basic Model, the past truth of certain sentences is even now up to us. Some might not find this objectionable on the grounds that a state of affairs like S's expressing a truth in 1958 is not something that really happened or occurred in 1958. It's not a genuine past event, like Napoleon's having been defeated at Waterloo. ${ }^{21}$ The point is that the past truth of a sentence about the future is a strange sort of "past" state of affairs, so maybe it's not so strange to think that it can even now be up to us. But what about genuine past events, can it be that we have counterfactual power over them?

On the Basic Model, God could give a human being this power, and it is epistemically possible that on occasion He has. Consider the following scenario: at a time T3 Smith does A. Because Smith does this, God eternally knows that Smith does A at T3. Because God knows this, God reveals to a prophet at T1, a much earlier time, that Smith will do A at T3, and God instructs the prophet to write this information down on a piece of parchment. The prophet does so, say, at T2 (also much earlier than T3). Then the event of the prophet's inscribing the information at T2 is explanatorily consequent to Smith's doing A at T3 - although it is temporally before Smith's doing A at T3. If Smith were to refrain from doing A at T3, God would not eternally believe that Smith does A at T3, and so God would not have revealed what He did to the prophet, and so the prophet would not have inscribed the parchment. If God were to actually do something like this, I think the thing to say would be that

(14) Smith has the power (long after T2) to do something such that, if he were to do it, then an event that occurred in the actual past (the prophet's inscribing the parchment in the way that he did at T2) would not have occurred.

This would be a counterfactual power over a genuine past event.

${ }^{21}$ See Linda Zagzebski, The Dilemma of Freedom and Foreknowledge, 26. 
Does God ever do this sort of thing? It's hard to know. But on the Basic Model it is epistemically possible that He does. So it's epistemically possible, according to the Basic Model, that we have counterfactual power over genuine past events. (Although no one ever exercises it, because God gets things right the first time around, so to speak.)

What I think these considerations show is that, given divine eternity, we might have something like a causal connection to events that are past. And this connection is sufficient for giving us control over such events. (Not control in a sense which involves the power to change such events, but control in the sense that what we do now might account for some past event's having occurred.)

To elaborate: given divine eternity, there could be something like backwards-in-time causation. What we might call 'standard' backwards causation would involve a later temporal event having an efficient causal effect on an earlier temporal event. The sort of backward causation relevant to our discussion involves eternity as well as time, and involves explanatory dependence as well as efficient causation. To use our previous example:

(a) Smith does A at T3.

(b) Because Smith does so, God eternally believes that he does so. (The 'because' here signifies a relation of explanatory dependence, not a relation of efficient causation.)

(c) In part because God believes that Smith does A at T3, God wills to reveal that Smith does A at T3 to a prophet at T1. (Again, this is explanatory dependence, not efficient causation.)

(d) Because God so wills, the prophet receives the revelation at T1. (Here we have efficient causation.)

(e) Because the prophet receives the revelation, he records the prophecy at $\mathrm{T} 2$.

On this story, an event at an earlier time (the recording of the prophecy) is dependent for its occurrence on an event at a later time (Smith's doing A). It is not correct to say that the later event has an efficient causal effect on the earlier event (because of the routing through God), but it's clear that the earlier event depends on the later. Let's call this backwards-intime explanation. While the Basic Model does leave us with the coun- 
ter-intuitive claim that humans could have counterfactual power over past events, it can also give a coherent account of how a person could manage to have such power. On the Basic Model, a person could have such a power because an act in that person's power to do or not to do could backwards-in-time explain a past event, given the requisite divine action.

\subsection{An objection relating to backwards-in-time explanation}

I now consider an objection to the view I'm defending that has to do with the possibility of circular explanation. Let's return to the thought experiment involving the discovery of an ancient manuscript containing the story of your life. One might object to the Basic Model as follows. If the Basic Model were true, then God could cause such a manuscript to be written, 1300 years before your birth. But if such a manuscript were written, it is possible that you might find it and read it, including the portion about your future. But once you read what your future actions were in the manuscript, you could choose to act differently in various ways. And if you could do that, you could make God wrong. But that is impossible. By reductio, the Basic Model must be false.

Assessing this objection requires us to take a close look at

(15) If such a manuscript were written, it is possible that you might find it and read it, including the portion about your future.

I'll now argue that (15) is false. For (15) to be true is for there to be a possible world in which God writes the story of your life and then permits you to find and read it (including the part about your future). But when we think carefully about what it would take for God to write such a book, we'll see that there is no such possible world. To put things loosely: God could not write such a story (the story of your life in which you found and read the completed story) because He would not know what to write.

To see this, note that although there are no temporally distinct steps an eternal God would have to go through to write a person's life-story, there is an order of logically distinct steps that would have to be followed. (Or, better: there is an order of logical dependency that would have to be 
respected.) For purposes of illustration, let's focus on four choices you'll make, in 2008, 2009, 2010, and 2011. In 2008, you chose between A and $\sim A$, in 2009 between $B$ and $\sim B$, and so forth. In this diagram, the arrows represent relations of explanatory dependence.

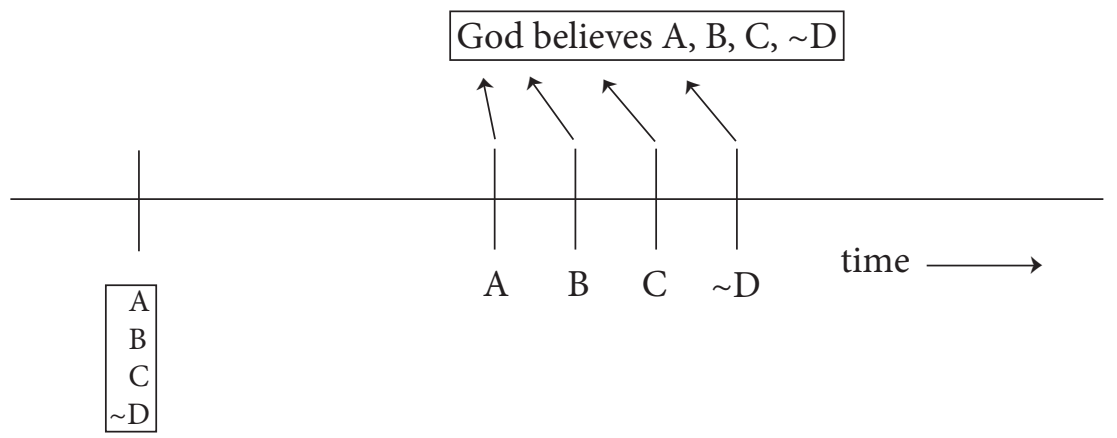

Because you choose A, God eternally knows that you choose A. Because you choose B, God eternally knows that you choose B. And so forth with $C$ and $\sim D$. In part because God knows all this, He has the book be written down at some point in time which is long past relative to the time you choose A. I assert that, so long as you never read a portion of the book describing your future, the situation represented in this diagram is metaphysically possible.

However, no story of your life could be written in which, midway through the story, you read the whole story. For in order for God to write the whole story of such a life (a life in which you find and read the whole story), God would first (not first in a temporal ordering, but first in a logical or explanatory ordering) have to see what you do in the course of your whole life, including the part of your life which follows your reading of the whole story. And in order for God to see what you do in the parts of your life that follow your reading of the whole story, you first (in the explanatory order) have to live the parts of your life that follow your reading of the whole story. And in order for you to live the parts of your life that follow your reading of the whole story, you first (in the explanatory and temporal orders) have to read the whole story. But in order for you to read the whole story, it first has to be written. So in order for God to write the whole story, it first has to be written. Since it is logically im- 
possible that such a requirement be fulfilled, it is logically impossible for there to be a possible world in which God writes the whole story of your life and permits you to read the whole thing. So (15) is false.

We can, I think, generalize from this example to formulate a principle about backwards explanation. If a human action A explains (at least in part) why (B) God believes something, and God's believing that something in turn explains (at least in part) why God causes an earlier event $\mathrm{C}$ to occur, then $\mathrm{C}$ cannot explain (even in part) the occurrence of $\mathrm{A}$.

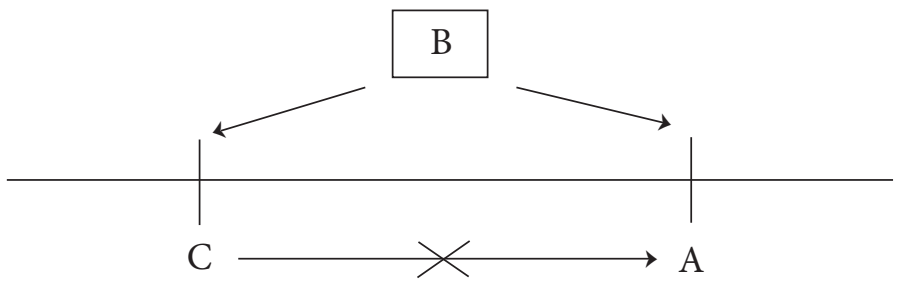

Otherwise, we would have an explanatory loop of the form: A occurred in part because $\mathrm{C}$ occurred, and $\mathrm{C}$ occurred in part because $\mathrm{B}$ occurred, and B occurred because A occurred. So A occurred in part because A occurred. This, it seems to me, is a metaphysically impossible sort of self-explanation. I think the thing to conclude is that an eternal God can act in such a way that a human action backwards-explains an earlier event, but He cannot act in any way that implies the existence of an explanatory loop.

We can apply this to the case of Christ's prophecy to Peter that Peter would deny him:

"Simon, Simon, listen! Satan has demanded to sift all of you like wheat, but I have prayed for you that your own faith may not fail; and you, when once you have turned back, strengthen your brothers." And he [Peter] said to him, "Lord, I am ready to go with you to prison and to death!" Jesus said, "I tell you, Peter, the cock will not crow this day, until you have denied three times that you know me."22

If Peter's hearing of this prophecy were an explanatory (or causal) factor in his decision to deny Christ, we would have an unacceptable explana-

${ }^{22}$ Luke 22:31-34 (New Revised Standard Version). See also Matthew 26:34, Mark 14:30, and John 13:38. 
tory loop: Peter denied Christ at $\mathrm{T}$ in part because Christ predicted that he would, but Christ predicted that he would because Peter denied Christ at T. Suppose, however, that God made Peter forget about the prophecy until after the denial. If God isolated the causal effect of the prophecy in the right way, then, it seems, there would be no explanatory loops involved. ${ }^{23}$ It's interesting to note that the gospels suggest that Peter had indeed forgotten about the prophecy at the time of his denial (see Luke 22:60-61).

\section{CONCLUSION}

In this paper I've presented a solution to the problem of freedom and foreknowledge. God is outside of time and has knowledge of events that are future with respect to us, simply because he "sees" them occur. I've argued that this solution does not falsely saddle us with a power to change the past or to change God's beliefs. On the model of divine eternity I've presented, however, we do have counterfactual power over God's eternal beliefs, and over the past truth of certain propositions. What is more, a person can even have, if God has made prophecies of a certain sort, counterfactual power over genuine past events. But these aren't good reasons to reject the eternity solution - they are simply consequences of the fact that backwards-in-time-explanation is possible, if God is eternal. ${ }^{24}$

${ }^{23}$ Alexander Pruss discusses this same case, and comes to the same conclusion, in an entry on Prosblogion, available at http://prosblogion.ektopos.com/archives/2009/08/ prophecy.html.

${ }^{24}$ I'm grateful to Timothy Pawl, Faith Pawl, Matthews Grant, Thomas Sullivan, and the participants in the God and the Future conference at Humboldt University in Berlin for their help in thinking through the issues discussed in this paper. 


\section{BIBLIOGRAPHY}

Hasker, William. “The Absence of a Timeless God." In God and Time: Essays on the Divine Nature, edited by Gregory E. Ganssle and David M. Woodruff, 182-206. Oxford: Oxford University Press, 2002.

Merricks, Trenton. "Truth and Freedom." The Philosophical Review 118:1 (2009): 29-57.

Rogers, Katherin. "The Necessity of the Present and Anselm's Eternalist Response to the Problem of Theological Fatalism." Religious Studies 43:1 (2007): 25-47.

Unger, Peter. "Free Will and Scientiphicalism." Philosophy and Phenomenological Research 65 (2002): 1-25.

Zagzebski, Linda. The Dilemma of Freedom and Foreknowledge. New York and Oxford: Oxford University Press, 1991.

Zagzebski, Linda. "Foreknowledge and Free Will." In The Stanford Encyclopedia of Philosophy (Fall 2008 Edition), edited by Edward N. Zalta, http://plato. stanford.edu/archives/fall2008/entries/free-will-foreknowledge/. 